を考えて，それと見かけの平均応力分布の和が真の平 均応力分布であると考充た. 以下, 応力振幅の求め方 は $\gamma_{f}=0$ の場合と全く同様である. 前飞 Fig. 13 亿描 ロを曲線はこのようにして計算した結果で, 実験結果 とよく一致している。

$$
\text { 7. 結言 }
$$

本研究により得られね主な結果は次の通りである。

(1) 疲労変形と繰遮数の関係 疲労による永久歪 は繰返数のごく初期汇起こり, 疲労降伏限以下の応力 では, 変形は一定值 $\gamma_{f}=0.2 \%$ 以下此まる。

（2）静降伏限度と疲労降伏限度の関係 疲労降伏 限度は静降伏限度にくらべて相当低くなる。したがつ
て，従来の酎久限度線図もこの疲労变形を考慮して使 用安全限界を定めるべきである。

（3）塑性加工の疲労降伏限度および耐久限度に及 ぼす効果 あらかじめ静降伏限度以上の静㨝り荷重を 加えるととにより, 疲労降伏限度和よび耐久限度は向 上する。その塑性加工の程度は承久歪 $1.0 \%$ を生和る 程度が適当であり，あまり大き過さることはかえつて

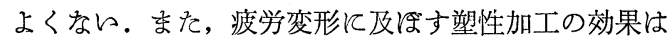
理論的にも, その傾向が求められるととを明らかてし ‡.

1) 河本実, 画葥却夫, 材料試験, 3 巻, 14 号, p. 52 , p. 58 (昭 29 )

\title{
線材の疲労強度に及ぼす引抜条件の影響*
}

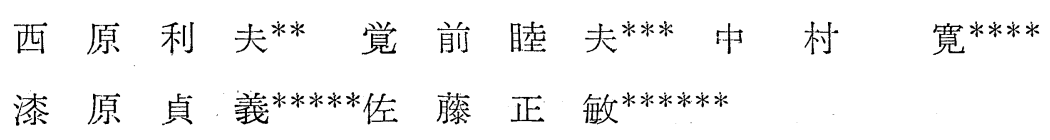

\section{The Effects of Drawing Conditions on the Fatigue Strength of the Drawn Wires}

\section{Toshio Nishinara, Mutsuo Kakuzen, Hiroshi Nakamura, Sadayoshi URushinara and Masatoshi Sato}

This paper deals with the experimental research on the effects of wire drawing conditions, mainly the shape of die wall and the amount of reduction of diameter in drawing on the fatigue strength of drawn wire.

We have investigated the endurance limit of $0.41 \%$ carbon steel wires drawn under several kinds of drawing conditions, using a Haigh-Robertson type fatigue testing machine.

Results obtained may be summerized as follows;

(1) The endurance limit of the wire drawn with a die of larger radius of curvature of drawing surface revealed higher than that of smaller radius.

(2) The endurance limit increased sharply with the increase of reduction of diameter in the range of low reduction, tending to a constant value when the reduction of diameter was more than $10 \%$.

\section{1. 緒言}

さきに0.10\%C 炭素鋼線材につレて, 回転曲げ疲労 試験を行々, 引抜条件, 主としてダイスの形状ならび に引拔直径減少率が線材の疲労強度に及ぼす影響につ いて検討を行つそが, 本論文ではさらに, 炭素含有量 が $0.41 \%$ の炭素鋼線材につ々て行つそ実験結果につ

\footnotetext{
* 原稿受付 昭和 30 年11月30日, 昭和 30 年 4 月日本機械学会に おいて講演

いて報告する。

\section{2. 実 験 方 法}

本実験に使用した炭素鋼線材は Table 1 亿示すよう な成分を有するものである。ます，所要の引抜值径減 少率を与えるように，あらかじめ適当な太さに引抜々 そ素線を $800^{\circ} \mathrm{C} て ゙ 30$ 分間真空焼鈍を行々，それまで

Table 1. Chemical composition of wire $(\%)$.

\begin{tabular}{c|c|c|c|c}
\hline $\mathrm{C}$ & $\mathrm{Si}$ & $\mathrm{Mn}$ & $\mathrm{P}$ & $\mathrm{S}$ \\
\hline 0.41 & 0.28 & 0.49 & 0.007 & 0.025 \\
\hline
\end{tabular}




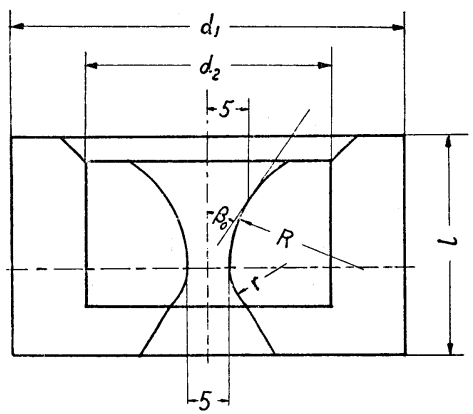

Fig. 1.

Table 2.

\begin{tabular}{c|c|c|c|c|c|c}
\hline $\begin{array}{c}\text { Symbol } \\
\text { of die }\end{array}$ & $\begin{array}{c}\beta_{0} \\
(\mathrm{deg})\end{array}$ & $\begin{array}{c}R \\
(\mathrm{~mm})\end{array}$ & $\begin{array}{c}r \\
(\mathrm{~mm})\end{array}$ & $\begin{array}{c}l \\
(\mathrm{~mm})\end{array}$ & $\begin{array}{c}d_{1} \\
(\mathrm{~mm})\end{array}$ & $\begin{array}{c}d_{2} \\
(\mathrm{~mm})\end{array}$ \\
\hline$C_{A}$ & 10 & $164 \cdot 8$ & 10 & 40 & 85 & 35 \\
$C_{C}$ & 30 & $18 \cdot 7$ & 5 & 25 & 48 & 24 \\
$C_{E}$ & 50 & 7 & 7 & 20 & 42 & 15 \\
\hline
\end{tabular}

に受けを加工による影響を完全に除去した後, Fig. 1 和よび Table 2 亿示すような形状寸法を有する 3 種類 の円弧ダイスを用いて引抜いを線材から試験片を切り 取つそ。

引抜にさいしては, 潤滑片としてモビール油に少量 のマシン油を加えをものを使用し，かつ，引拔中の熱 の発生により線材が自己尭鈍されるのを防ぐをめに, 引拔速度を約 $40 \mathrm{~cm} / \mathrm{min}$ の低速保つた。

な扣, ダイスの孔径を $d_{0}$, 引抜前の素線の径を $d_{1}$ と すれば, 引拔直径減少率 $\psi$ は次式で与えられる。

$$
\psi=\frac{d_{1}-d_{0}}{d_{1}} \times 100 \%
$$

本実験では， $\varphi$ 走 $4 \cdot 1 \% ， 9 \cdot 8 \%$ ，およ゙ 13・6\%の 3 種にとつた。

以上のようにしてえられを試験片線材を, HaighRobertson 式針金綎返曲げ疲労試験機を用的て実験を 行つた。.この際, 試験片の長さは線材の直径の 120 倍 にとつた。

\section{3. 実 験 結 果}

引抜直径減少率 $\psi$ が $4 \cdot 1 \%, 9 \cdot 8 \%$ ，和よび 13.6\%， の各場合につレて, 切線角 $\beta_{0}$ がそれぞれ $10^{\circ}, 30^{\circ}$, 和よび $50^{\circ}$ である $C_{A}, C_{C}$ ，利よど $C_{E}$ 各ダイスで引 抜々た線材の応力一絽返数線図を Fig. 2 Fig. 4 亿示 す. そだし，Fig. 2 中の $C_{0}$ なる線図は素線に対する もので，焼鈍により加工の影響を除らそ線材の試験結 果である。な和, $1 \times 10^{7}$ の繰返数に対して試験片線材 が破断しないときの最大応力をもつて疲労強度とした。

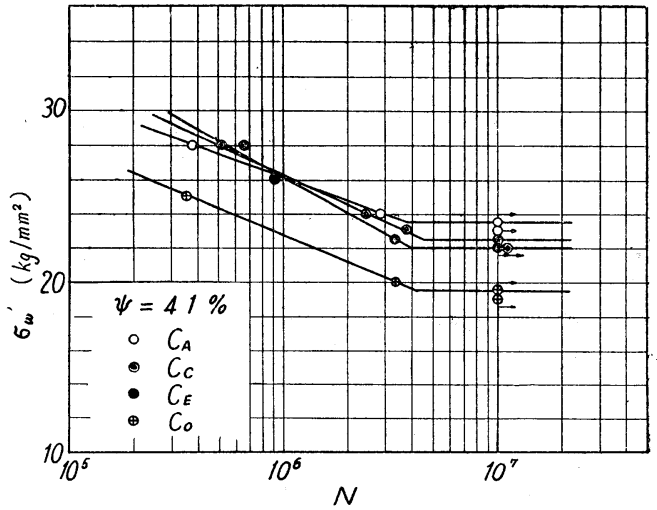

Fig. 2. Stress-endurance diagram.

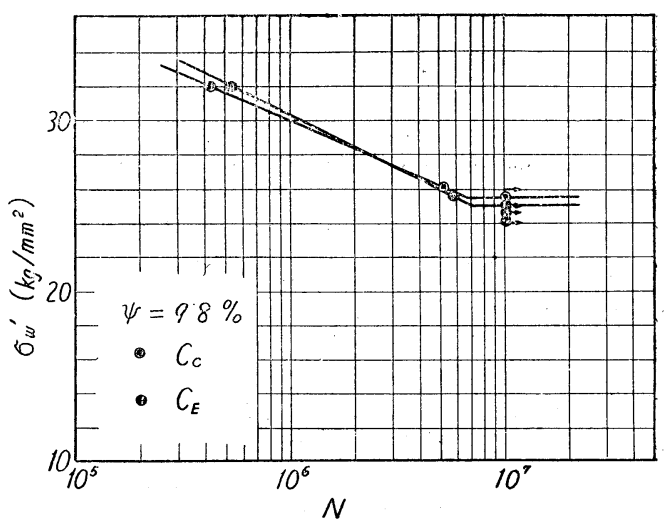

Fig. 3. Stress-endurance diagram.

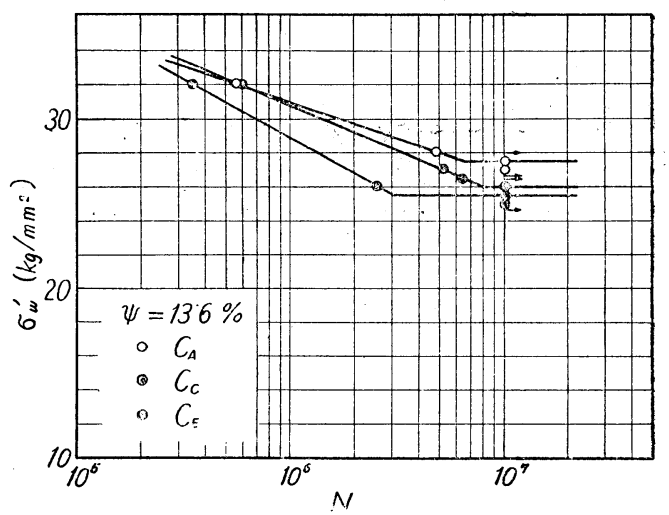

Fig. 4. Stress-endurance diagram.

\section{4. 引抜条件の影響}

（1）ダイス形状の影響 引抜直径减少率 れぞれ 4.1\%，9・8\%，和よび 13.6\%の線材について， ダイスの形状が疲労強度に及ぼす影響を明らかにする ために,ダイスの形状を表わすパラメーターとして $\beta_{0}$ をとり，疲労強度 $\sigma_{w}{ }^{\prime}$ との関係を示すと Fig. 5 亿示す ような結果が得られる。すねわち, 引抜直径減少率が 同じときには, 線材の回転曲げに対する疲労強度はダ 


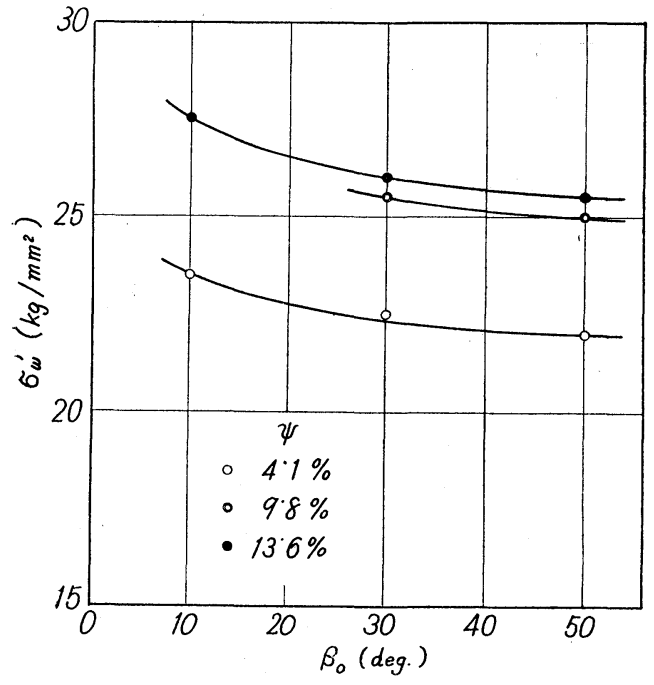

Fig. 5. Effects of the shape of die on the endurance limit of the drawn wire.

イスの引抜面の曲率が小さくなるにつれて増大する傾 向を示し, これは,さきに $0.10 \% \mathrm{C}$ 炭素鋼線材につ いてえられそ結果と全く同様である。

（2）引抜直径減少率の影響 引拔面の曲率の異 なる $C_{A}, C_{C}$ ，执よび $C_{E}$ 各ダイスで引抜らた線材に つ々て, 引抜直径減少率が線材の疲労強度に及㳊す影 響を明らかにするために, 引抜直径減少率 $\phi$ と疲労 強度 $\sigma_{w}{ }^{\prime}$ との関係を示すと. Fig. 6 のよう.結果が得ら れる.すなわち, ダイスの形状が同じときには, 線材 の回転曲げに対する瘦労強度は引抜直径減少率が増加 するにつれて増加するが，乙の増加の割合は引抜直径 減少率の増加につれて漸次小さくなり, 引抜直径減少 率が10\%以上になると, 疲労強度の増加はほとんど期 待できならのであつて，乙れも0・10\%C炭素鋼線材に

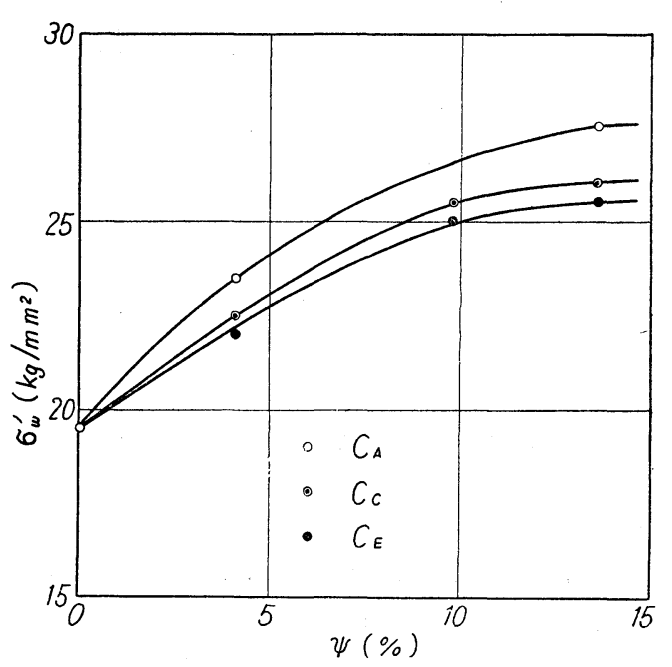

Fig. 6. Effects of reduction of diameter on the endurance limit of the drawn wire.

つマて行つた実験結果と症同様な傾向を示している.

\section{5. 結諭}

炭素含有量 $0.41 \%$ 炭素鋼線材につ々て, 引拔条件, 主としてダイスの形状ならどに引抜值径減少率が線材 の回転曲げ疲労強度に及ぼす影響につレて明らかにす るととができた。

すなわち, 引抜面の曲率の小なるダイスを用いる质 ぞ, また, 引抜直径減少率を大きくするほど, 線材は 高疲労強度を示している. そして引抜直径減少率が 小なる間は, これの増加と共に疲労強度は急激に增す が, 引抜值径減少率が10\%以上では疲労強度はほとん ぞ増加しない。

洼 ; -

1) 材料陚験, 4,24, p. 378 